\title{
THREE CARIDEAN SHRIMPS ASSOCIATED WITH A MEDUSA FROM TANABE BAY, JAPAN
}

$\operatorname{AUTHOR}(S)$ :

Hayashi, Ken-ichi; Miyake, Sadayoshi

\section{CITATION:}

Hayashi, Ken-ichi ...[et al]. THREE CARIDEAN SHRIMPS ASSOCIATED WITH A MEDUSA FROM TANABE BAY, JAPAN. PUBLICATIONS OF THE SETO MARINE BIOLOGICAL LABORATORY 1968, 16(1): 11-19

\section{ISSUE DATE:}

1968-06-29

URL:

http://hdl.handle.net/2433/175493

RIGHT: 


\title{
THREE CARIDEAN SHRIMPS ASSOCIATED WITH A MEDUSA FROM TANABE BAY, JAPAN ${ }^{1)}$
}

\author{
Ken-Ichi HAYASHI and SADAYoshi MIYAKE \\ Zoological Laboratory, Faculty of Agriculture, Kyushu University
}

With 4 Text-figures

In southern Japan, the association between rhizostomian medusae and small shrimps is sometimes observed by field biologists and fishermen, and the host medusae are well known and have often been studied, but little attention has been paid to the associated shrimps.

During his biological observations on medusae, Mr. Châichi Araga, Seto Marine Biological Laboratory, Kyoto University, found a number of shrimps associated with the medusa, Mastigias papua L. Agassiz. These shrimps are represented by 28 specimens of three caridean species, Chlorotocella gracilis BALss, Latreutes anoplonyx KEMP and L. mucronatus (STimpson).

Of these the second species, L. anoplonyx, previously reported as a commensal shrimp with medusae (DE MAN, 1929; Holthuis, 1947; LiU, 1955), is probably new to the fauna of Japan. Although the other two species were also recorded in literature as such commensal shrimps (Johnson, 1961; KuBo, 1965), the detailed data of them were not given. On the other hand, no previous records of $L$. anoplonyx on this host, $M$. papua, are known to us. Since little is known of the commensalism between rhizostomian medusae and caridean shrimps the following descriptions may be of interest.

We are very grateful to Dr. Itsuo Kubo, Tokyo University of Fisheries, for providing us with the valuable reference and personal communications, especially concerning Chlorotocella gracilis, and Dr. Tohru Uchida, the Emeritus Professor of the Hokkaido University, for his kind information of the medusae and its associated shrimps. We are also indebted to Mr. Chuichi Araga for sending us the shrimps and the ecolbgical data of them.

\section{Material}

All specimens of the material were found among the complicatedly ramified oral

1) Contributions from the Zoological Laboratory, Faculty of Agriculture, Kyushu University, No. 375 and Contributions from the Seto Marine Biological Laboratory, No. 483.

Publ. Seto Mar. Biol. Lab., XVI (1), 11-19, 1968. (Article 3) 
arms of about ten individuals of Mastigias papua (diameter of umbrella, $11-14 \mathrm{~cm}$ ) collected in Ikeda-Ura, a cove at the bottom of Tanabe Bay, on October 5, 1965 by Mr. C. Araga.

The composition of the specimens is as follows:

Chlorotocella gracilis BALss …........ 2 송, 2 ovig. 우우, 1 우 (ZLKU No. 10814)

Latreutes anoplonyx KEMP …............ 3 송ㅎㅇ, 3 ovig. 우우, 3 우우 (ZLKU No. 10819)

Latreutes mucronatus (STIMPSON) ….4 5 송, 4 ovig. 우우, 6 우우 (ZLKU No. 10828)

\section{Description}

Family Pandalidae

\section{Chlorotocella gracilis BALSS}

(Figs. la-c and $4 a$ )

Chlorotocella gracilis BALss, 1914, p. 33, figs. 16-22-Sagami Bay, Japan (Type locality); DE MAN, 1920, p. 180, pl. 15 fig. 45, 45a-Java and between the islands of Miscool and Salawatti; KEмP, 1925, p. 278-Andaman Is. and Nicobars; NAKAzAWA, 1927, p. 1015, fig. 1952-No new locality; Nakazawa and Kubo, 1947, p. 779, fig. 2247-No new locality; Holthuis, 1955, p. 127, fig. 90-No new locality; Johnson, 1961, p. 47-Singapore; Kuвo, 1965, p. 612, fig. 960-Amakusa Is.

The body is very slender ranging $16-20 \mathrm{~mm}$ in length (Fig. la). The rostrum is long, slender and slightly curved upwards near the distal part, being 1.4 times as long as the carapace. The upper border of the rostrum is armed with a distinct tooth at the proximal part. There is also a very small tooth on the lower border of the rostrum near the apex (Fig. 1b). The suborbital angle is produced forward as a blunt process which is separated from the antennal spine by a notch. The supraorbital and pterygostomian spines are present. There is a tooth on the gastric region of the carapace, which is smaller than the upper rostral one.

The abdomen is smooth on the dorsal border, but has a spine on posterior margin of the terga of the fourth and fifth somites, except for one specimen (ZLKU No. 10815 ), in which the fifth somite bears an accessory spine on the posterior margin of pleuron. There is a shallow pit on the dorsal side, near the posterior margin of the fourth somite. The sixth somite is very long, about three times as long as the fifth, and terminates in a small spine at the middorsal line. The telson is armed with one pair of dorsal spines and eight to eleven pairs or asymmetrical numbers of dorsolateral spines.

The eye is long and subcylindrical, reaching the distal end of the first segment of the antennular peduncle. The cornea is shorter than the stalk. The antennular peduncle fails to reach the apex of the scaphocerite; the first segment is long and provided with the short stylocerite which reaches the middle of the segment; the second and the third are very short, and the top of the third is armed with a small spine. The scaphocerite is long, extending to the middle of the rostrum. 
The mouth-parts agree with BALss' figures; the mandibular palp is slender and two-jointed; the incisor process bears five large teeth on the distal edge and four small ones on the lower margin near the distal edge; the molar process has a few blunt knobs with brush-like hairs (Fig. lc). The third maxilliped is long, slender and extends to the apex of the scaphocerite.

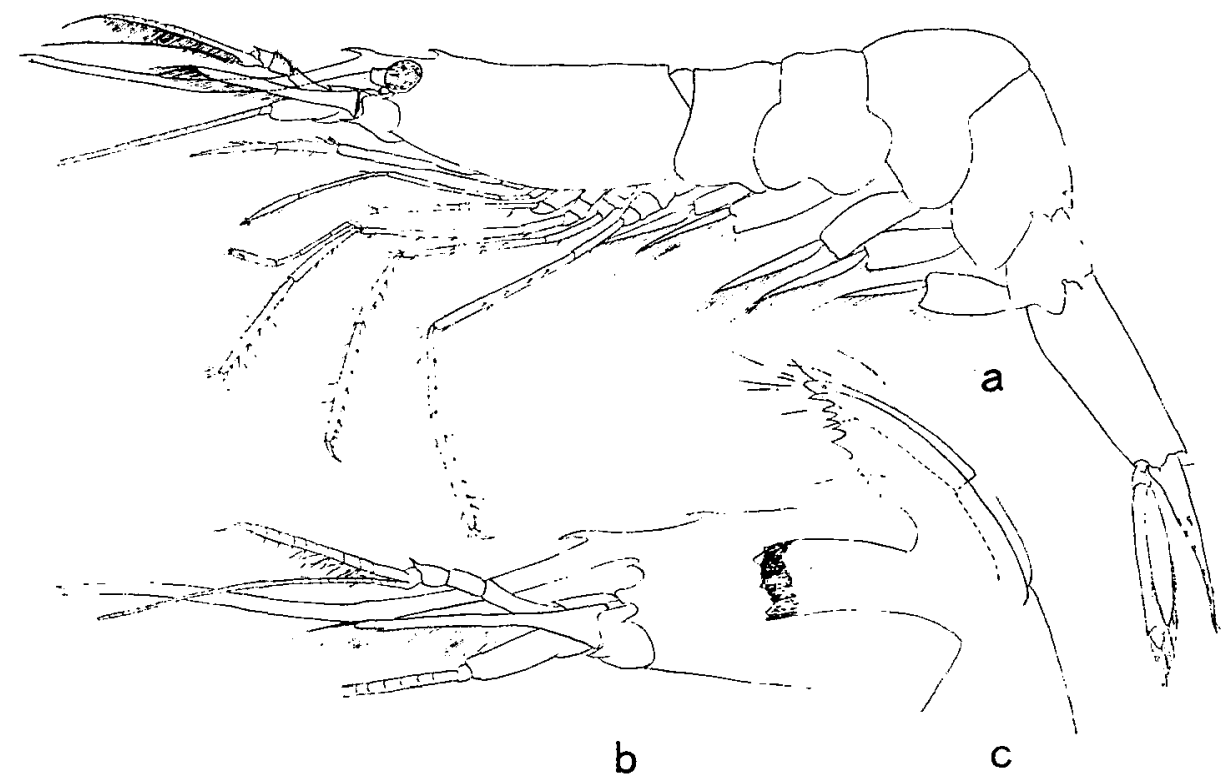

Fig. 1. Chlorotocella gracilis BALss.

a, Male, $\times 6.7$; b, anterior part of carapace of fernale (eye removed), $\times 10.0$; $c$ mandible.

The branchial formula is as follows:

\begin{tabular}{lccccccccc} 
& \multicolumn{3}{c}{ Maxillipeds } & \multicolumn{4}{c}{ Pereiopods } \\
& 1 & 2 & 3 & 1 & 2 & 3 & 4 & 5 \\
Pleurobranchs & - & - & - & 1 & 1 & 1 & 1 & 1 \\
Arthrobranchs & - & - & - & & - & - & - & - & - \\
Podobranchs & - & - & - & & - & - & - & - & - \\
Epipods & 1 & 1 & 1 & & - & - & - & - & - \\
Exopods & 1 & 1 & - & - & - & - & - & -
\end{tabular}

The first pereiopod is also slender and not chelate; the distal segment is shorter than the carpus. The chela of the second pereiopod is small; the carpus is composed of three joints which are decreasing in length toward the distal one; the merus and ischium are subequal in length. The following three pereiopods are similar in shape and length. The dactylus is slender, having a short spine near the base (Fig. 4a). The propodus is armed with seven or eight slender spines on the lower margin, 
and the carpus has two small spines. The merus of the third pereiopod bears three or four spines on the lower margin. There are four outer and two or three lower spines on the merus of the fourth pereiopod. The merus of the fifth pereiopod is armed with four or five outer and only one lower spines. There is only one spine on the lower surface of each ischium of the third and fourth pereiopods.

The sexual differences are not obviously present, but the upper antennular flagellum is longer in males than in females (Fig. 1b).

The eggs are small and numerous.

\section{Family Hippolytidae}

\section{Latreutes anoplonyx KEMP}

(Figs. 2a-b and $4 \mathrm{~b}$ )

Latreutes anoplonyx KEMP, 1914, p. 104, pl. 4 figs. 3-5-Bombay (Type locality); KEMP, 1916, p. 399Bombay and Burma; de MAN, 1929, p. 130, fig. 8-Near Batavia; Holthuis, 1947, p. 16 and p. 60-Off Batavia and E. Java; Lru, 1955, p. 42, pl. 15 figs. 1-9-Four coastal provinces (Liaoning, Hopeh, Shantung, Kiangus) in north and central China.
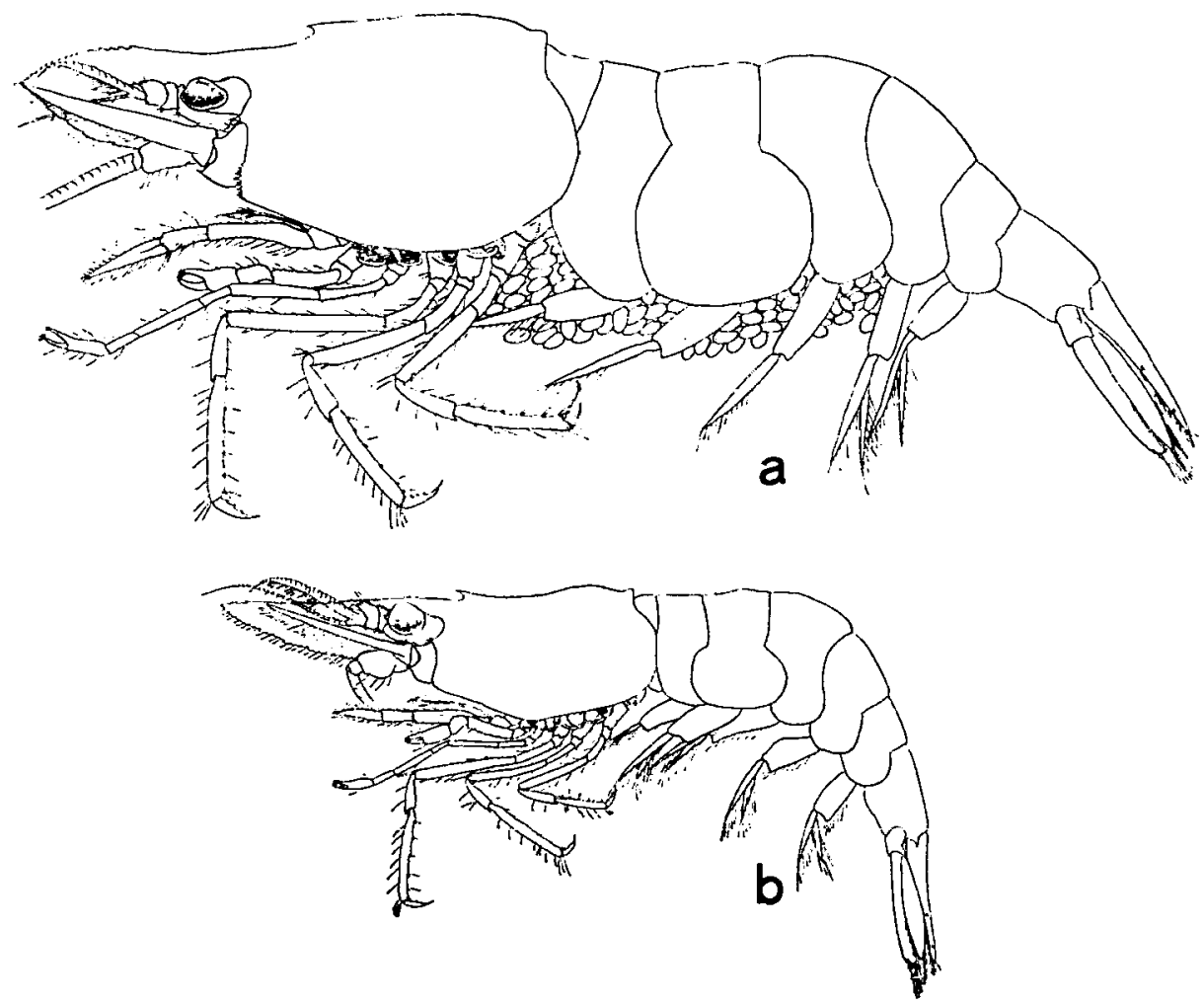

Fig. 2. Latreutes anoplonyx KEMP.

a, Ovigerous female, $\times 6.3 ; \mathrm{b}$, male, $\times 6.3$. 
The sexual differences are clearly observed in several external characters, such as the body length, the shape as well as spinulation of the rostrum and the length of the upper antennular flagellum (Fig. 2a-b). The body length is $15-18 \mathrm{~mm}$ in ovigerous females and $10-12 \mathrm{~mm}$ in males. The rostrum is triangular and much narrower and longer in males than in females. The upper border of the rostrum is armed with 14-20 teeth in females and 8-10. in males. There are 9-15 teeth on the lower border of the rostrum in females and 7-8 in males. The carapace bears a small tooth on the gastric region, being smooth on postrostral and posterior median part. The antennal spine is present and the pterygostomian angle is serrated with 8-13 spinules.

The abdomen is smooth, and the third abdominal somite is not so produced to cover the fourth somite as in the forgoing species. The telson is longer than the sixth somite, and provided with two small spines on the dorsal surface of the distal half.

The eye is short, reaching anteriorly the first segment of the antennular peduncle. There is a small process on the inner distal part of the eyestalk. The antennular peduncle is short, the first segment is provided with a small marginal spine; the upper antennular flagellum is stouter and broader in males than in females, composed of 20-21 joints in males and 9-13 in females. The scaphocerite ends in a sharp point, being about four times as long as broad.

The mandible bears neither incisor process nor palp. The third maxilliped reaches the middle of the upper antennular flagellum in females, but it reaches only the base of the antennular flagellum in males.

The branchial formula is as follows:

\begin{tabular}{lccccccccc} 
& \multicolumn{3}{c}{ Maxillipeds } & \multicolumn{4}{c}{ Pereiopods } \\
& 1 & 2 & 3 & 1 & 2 & 3 & 4 & 5 \\
Pleurobranchs & - & - & - & 1 & 1 & 1 & 1 & 1 \\
Arthrobranchs & - & - & - & & - & - & - & - & - \\
Podobranchs & - & - & - & & - & - & - & - & - \\
Epipods & 1 & 1 & 1 & & 1 & 1 & 1 & 1 & - \\
Exopods & 1 & 1 & 1 & & - & - & - & - & -
\end{tabular}

The first pereiopod is robust and short, not reaching the penultimate segment of the third maxilliped. The second pereiopod is slender, extending to the rostral apex in females, while it reaches the distal tip of the third maxilliped in males. The carpus of the second pereiopod is subdivided into three joints. The following three pereiopods are similar in shape. The dactylus is a simple claw with four spinules (Fig. 4b). The propodus is armed with six spines on the lower margin; the merus is provided with only one spine near the outer side of the distal articulation.

The eggs are small and numerous, measuring $0,27 \times 0.35 \mathrm{~mm}$ in diameter. 


\section{Latreutes mucronatus (STIMPSON)}

(Figs. 3a-b and $4 c$ )

Rhynchocyclus mucronatus Stimpson, 1860, p. 96 (28)-Hong Kong (Type locality).

Latreutes mucronatus: KEMP, 1914, p. 101, pl. 3 figs. 8-15, pl. 4 figs. 1, 2-South India; Balss, 1914, p. 47, fig. 27-Sagami Bay, Korea and Gulf of Siam; KEMP, 1916, p. 296-Andaman Is.; URiTA, 1926, p. 426-Tsingtao, north China; YU, 1935, p. 50-Pehtaiho, Kinchow Bay, north China; Holthuis, 1947, p. 17 and p. 60-Djedan I. and Makassar Strait; BARNARD, 1950, p. 706, fig. 131a, b-Durban; Johnson, 1961, p. 48-Singapore.

non Latreutes mucronatus: Doflein, 1902, p. 638, pl. 5 fig. 6 [三L. planirostris (DE HAAN)].

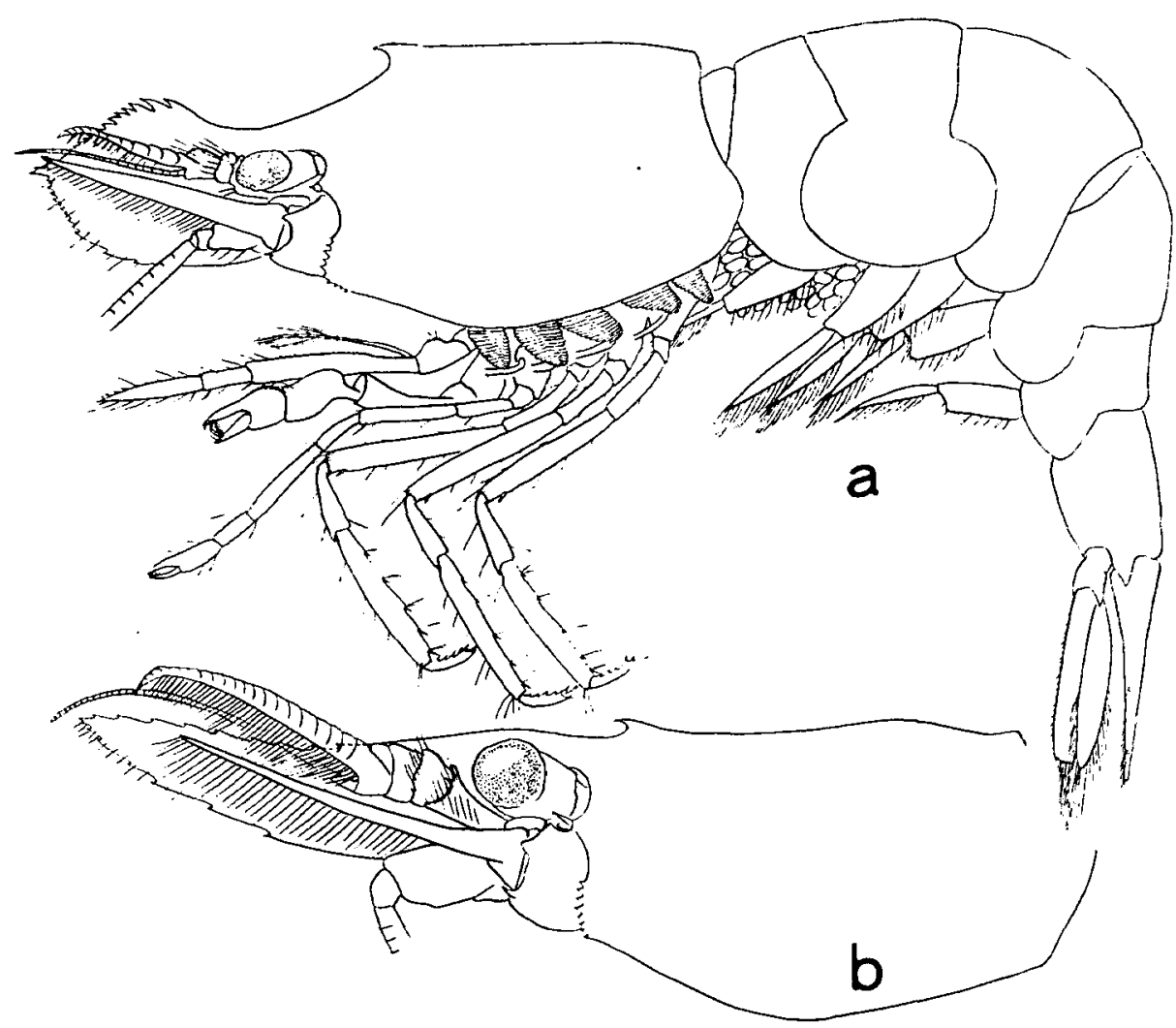

Fig. 3. Latreutes mucronatus (Stimpson).

a, Ovigerous female, $\times 10.0 ; \mathrm{b}$, anterior part of body, male, $\times 15.3$.

The species shows the sexual differences to the same extent as in L. anoplonyx (Fig. 3). Males(9-12 mm in body length)are much smaller and slenderer than females $(15-17 \mathrm{~mm})$. The rostrum is much narrower and longer in males than in females, and provided with 9-10 teeth on the upper border and 7-8 on the lower in males and with 15-19 teeth on the upper border and 11-13 on the lower in ovigerous fe- 
males. The upper antennular flagellum is stouter and broader in males (20-21 joints) than in females (9-13 joints).

These variations in the present species parallel closely those of $L$. anoplonyx, but there are some differences between these two species. The rostrum of the female is more orbicular in $L$. mucronatus than in any specimens of $L$. anoplonyx, though the male's is almost the same in both species. The carapace is armed with a tooth on the gastric region which is rather larger in L. mucronatus than in L. anoplonyx. The last three pereiopods of the present species are subequal in shape and length; the dactylus is biunguiculate with four spines ranging along the lower margin (Fig. 4c),

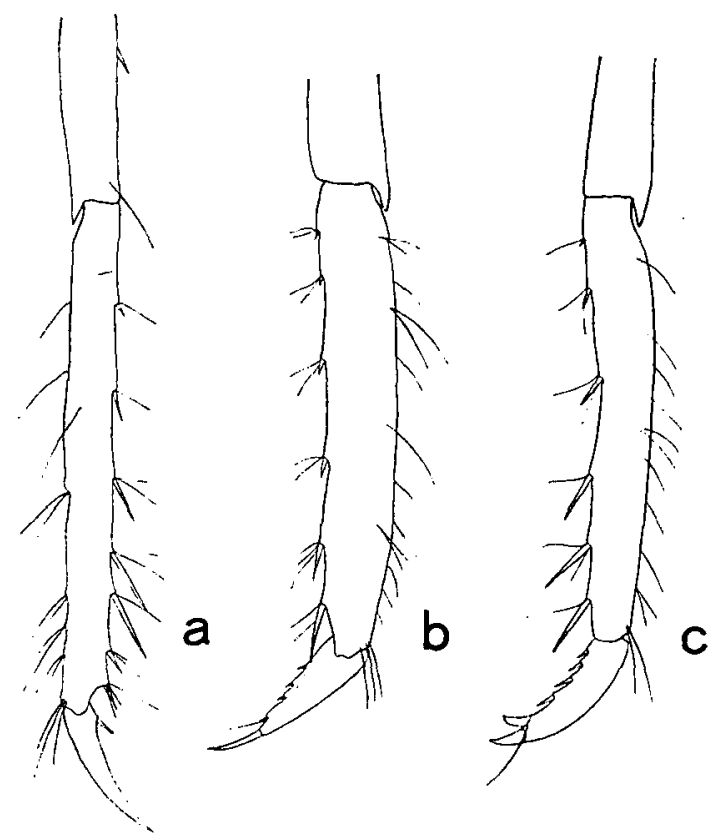

Fig. 4. Dactylus and propodus of the third pereiopod in three species of commensal shrimps. $a$, Chlorotocella gracilis BALss, b, Latreutes anoplonyx KEMP, c. Latreutes mucronatus (STIMPson).

but it is a slender claw with four spinules on the lower margin in L. anoplonyx (Fig. 4b); the propodus has six slender spines on the lower margin, of which the distal three are usually longer than those in L. anoplonyx.

\section{Discussion}

It is a very interesting fact that the pandalid and the hippolytid shrimps associate with medusae, which are rejected by pontoniids as commensal partners. According to Dr. UchidA, the association between medusae and shrimps was previously reported 
by the investigators of medusae. He referred to its commensalism in his comprehensive description of Mastigias papua L. Agassiz (1926) as follows: "In October large dark brown medusae [Mastigias papua] were often to harbour commensal shrimps of the same colour with the eggs." KishinouYe (1902) also described another rhizostomian medusa, Netrostoma setouchiana (KISHINouYe), under the Japanese name "Yebikuragé (Shrimp medusa)," for a commensal shrimp was found under its umbrella. Since then these medusae have been known to be associated with some shrimps in Japan, but the detailed data of such association have not yet been presented.

The first species, Chlorotocella gracilis, has been considered to be sub-planktonic or nektonic, from its general form. Indeed, the most specimens of this species have been collected in the surface waters by the plankton net, though the type specimens were collected from a considerable depth $(80-130 \mathrm{~m})$. Recently, Kuво (1965) described it as a shrimp commensal with a medusa, but unfortunately without any further detailed data. On the other hand, Latreutes anoplonyx has several times been reported as a shrimp commensal with medusae: DE MAN (1929) found three females in a species of Rhizostoma(?), Holthuis (1947) described only one ovigerous female taken from the subgenital cavity of Acromitus flagellatus (HäckeL) and LiU (1955) collected many specimens attaching to the oral arms of Rhopilema esculenta KishinoUYE. The last species, L. mucronatus, was listed by JoHnson (1961) as a shrimp commensal with medusa, but he could not confirm this association in the sea near Singapore; while many other authors have made no comments on the commensalism of this shrimp with medusae.

The second species seems to have a close connection with medusae, but in the other two species the commensalism is thought to be rather loose than in $L$. anoplonyx, as free swimming individuals of them are sometimes collected.

According to Mr. Araga, two rhizostomian medusae are found in Tanabe Bay. The one, Mastigias papua, is one of the commonest medusae found in the littoral waters along the Pacific coast of middle to southern Japan, but the occurrence of its associated shrimps has been extremely rare in that bay. Both the host medusa and the associated shrimps must be the warm water animals which are distributed northwards by the Kuroshio. Then, this commensalism must be much more stable in the tropical and subtropical regions than in middle Japan. With regard to the other medusa, Netrostoma setouchiana, in Tanabe Bay no data are available as to the commensalism so fár.

\section{REFERENGES}

Balss, H., 1914. Ostasiatische Decapoden II. Die Natantia und Reptantia. In: Dorlein, F., Beiträge zur Naturgeschichte Ostasien. Abh. math.-phys. Kl. K. Bayer. Akad. Wiss., suppl. vol. 2, pt. 10, pp. 1-101, figs. 1-50, pl. 1.

Barnard, K.H., 1950. Descriptive catalogue of South African decapod Crustacea. Ann. S. Afr. Mus., vol. 38, pp. 1-837, figs. 1-154. 
Dofleiv, F., 1902. Ostasiatische Dekapoden. Abh. math.-phys. Kl. K. Bayer. Akad. Wiss., vol. 21, pp. 613-670, figs. A-D, pls. 1-6.

Holthurs, L.B., 1947. The Decapoda of the Siboga Expedition. Part IX. The Hippolytidac and Rhynchocinetidae collected by the Siboga and Snellius Expeditions with remarks on other species. Siboga Exped., monogr. 39 a8, pp. 1-100, figs. 1-15.

, 1955. The recent genera of the Caridean and Stenopodidean shirimps (Class Crustacea, Order Decapoda, Supersection Natantia) with keys for their determination. Zool. Verh. Rijksmus. Nat. Hist. Leiden, vol. 26, pp. 1-157, figs. 1-105.

Johnson, D.S., 1961. A synopsis of the Decapoda Caridea and Stenopodidea of Singapore, with notes on their distribution and a key to the genera of Caridea occurring in Malayan waters. Bull. Nat. Mus. Singapore, no. 30, pp. 44-79, pl. 2.

Kemp, S., 1914. Notes on Crustacea Decapoda in the Indian Museum. V. Hippolytidae. Rec. Ind. Mus., vol. 10, pp. 81-129, pls. 1-7.

-, 1916. Notes on Crustacea Decapoda in the Indian Museum. VII. Further notes on Hippolytidae. Ibid. vol. 12, pp. 385-405, figs. 1-5, pl. 36.

- 1925. Notes on Crustacea Decapoda in the Indian Museum. XVII. On various Caridea. Ibid., vol. 27, pp. 249-343, figs. 1-24.

Kishinouye, K., 1902. Some new Scyphomedusae of Japan. Jour. Coll. Sci., Imp. Univ. Tokyo, vol. 17 , art. 7, pp. 1-17, pls. $1,2$.

Kubo, I., 1965. Macrura. In: Okada, Y.K., Uchida, S., Uchida, T. and others, New illustrated Encyclopedia of the fauna of Japan. Part II. pp. 591-629, figs. 892-1031. Hokuryu-Kan, Publishing Co., Ltd., Tokyo (in Japanese).

LiU, J.Y., 1955. Economic shrimps and prowns of northern China. Marine Biological Institute, Academy of Sciences Peking, pp. i-iii, 1-73, pls. 1-24 (in Chinese).

DE MAN, J.G., 1920. The Decapoda of the Siboga Expedition. Part IV. Family Pasiphaeidac, Stylodactylidae, Hoplophoridae, Nematocarcinidac, Thalassocaridae, Pandalidae, Psalidopodidae, Gnathophylidae, Processidae, Glyphocrangonidae and Crangonidae. Siboga Exped., monogr. 39 a3, pp. 1-318, pls. 1-25.

- 1929. On a small collection of Decapoda, one of which a Crangon, caught by the Danish Pacific Expedition at the Jolo Islands, is new to science. Papers from Dr. Th. Mortensen's Pacific Expedition 1914-16. L. Vidensk. Medd. naturh. Foren. Kbh., vol. 87, pp. 105-134, figs. 1-9.

Nakazawa, K., 1927. Decapoda. In: Uchida, S. and others, Figuraro de Japanaj bestoj., pp. 9921124, figs. 1910-2166. Hokuryukwan \& Co., Ltd., Tokyo (in Japanese).

—_- Macrura. In: Uchids, S. and others, Illustrated Encyclopedia of the fauna of Japan. Rev. ed., pp. 751-797, figs. 2172-2303, pl. 6. Hokuryukan Co., Ltd., Tokyo (in Japanese).

Stimpson, W., 1860. Prodoromus descriptionis animalium evertebratorum, quae in Expeditione ad Oceanum Pacificum Septentrionalem, a Republica Federata missa, C. Ringgold et J. Rodgers Ducibus, observavit et descripsit. Proc. Acad. nat. Sci. Philad., 1860, pp. 91-117 (22-48).

UchidA, T., 1926. The anatomy and development of rhizostome medusa, Mastigias papua L. Agassiz, with observation on the phylogeny of Rhizostomae. Jour. Fac. Sci., Univ. Tokyo, sect. 4. Zool., vol. 1, pt. 1, pp. 45-95, pl. 4.

Urita, T., 1926. On decapods from Tsingtao, China. Zool. Mag., vol. 38, pp. 421-438 (in Japanese). Yu, S.C., 1935. Sir la famille des Hippolytidae de la Chine. Chinese Jour. Zool., vol. 1, pp. 41-54, fig. 1. 